\title{
Differential effects of age-structured common carp (Cyprinus carpio) stocks on pond invertebrate communities: implications for recreational and wildlife use of farm ponds
}

\author{
Janusz Kloskowski
}

Received: 15 June 2010/ Accepted: 23 February 2011/Published online: 8 April 2011

(C) The Author(s) 2011. This article is published with open access at Springerlink.com

\begin{abstract}
Sustainable development of common carp Cyprinus carpio pond fisheries in Europe postulates their multifunctional use, integrating exploitation of aquaculture resources with recreational services and maintenance of high levels of local biodiversity. Age classes of farmed carp are grown separately and pond ecosystems may be differently affected by different ontogenetic stages of fish. To examine these relationships, a study was conducted on spring and summer diet of carp, invertebrate abundance and community structure, and water quality characteristics in ponds stocked with three carp age classes in SE Poland. With the exception of young-of-the-year fish in spring, benthic dipterans prevailed in the diets of all carp age classes and their consumption increased from spring to summer. Zooplankton featured in the diet of carp only in spring. Medium- and large-sized cladocerans predominated among microcrustaceans found in the guts of one- and two-yearold carp. Consequently, in summer, total biomass of medium- and large-sized cladoceran grazers was substantially lower in ponds stocked with older-age fish than in ponds used for production of 1-summer-old fingerlings. The relatively sparse submerged vegetation cover and low water transparency in ponds with older fish stocks compared to ponds with youngof-the-year carp indicate a transition to a turbid water state mediated by a trophic cascade mechanism in the presence of older-age fish. Densities of water-column macroinvertebrates decreased with the age of carp in the ponds. These results suggest that non-aquaculture use of carp ponds should be diversified according to their environmental quality. Fingerling rearing ponds are more suitable for environmentally friendly multifunctional use than ponds with older stocks.
\end{abstract}

Keywords Common carp · Multifunctional aquaculture · Pond fisheries · Size-structured interactions $\cdot$ Sustainable use $\cdot$ Trophic cascade 


\section{Introduction}

In Europe, carp fishes (common carp Cyprinus carpio and the so-called Chinese carps, silver carp Hypophthalmichthys molitrix, bighead carp Hypophthalmichthys nobilis and grass carp Ctenopharyngodon idella) are grown in man-made, open, shallow ponds, typically originating from natural wetlands, but their environmental conditions are to a large extent under human control. Carp are often reared in a polyculture, but in cold climate regions monoculture of common carp is more popular (Opuszyński 1981; Milstein 1992; Szücs et al. 2007). The common carp (hereafter: carp) is a species capable of substantial impact on aquatic ecosystems. While the carp itself is highly tolerant of environmental stress, its benthic feeding habits are responsible for severe habitat alteration. In eutrophic waters, carp may trigger a shift from clear-water conditions to a turbid, macrophyte-poor state accompanied by a sharp decline in biodiversity (Scheffer 1990; Weber and Brown 2009). On the other hand, carp pond-complexes have been recognised as strongholds for waterbirds and amphibians (Grimmet and Jones 1989; IUCN 1997; Kloskowski 2010) and as providers of cultural services to humans (EPCN 2007). In countries belonging to the European Union (EU), one of the basic goals of the Common Fisheries Policy, the EU's principal instrument for aquaculture management, is the development of the pond fisheries industry towards a sustainable aquaculture sector. Relevant aquaculture policies imply maintenance of local biodiversity and sustained delivery of services for various recreational activities (Aps et al. 2004; Szücs et al. 2007). The implementation of environmentally sensitive farming practices is financially encouraged by Axis 2 of the European Fisheries Fund 2007-2013 (Council Regulation No 1198/2006). The demand for multifunctionality in pond aquaculture may be necessary for the economic survival of many carp farms, especially in Central and Eastern Europe, since the economic benefits from the production of cyprinids have decreased in recent years (Aps et al. 2004; Bekefi and Varadi 2007). However, non-aquaculture services often require the preservation of high environmental and aesthetic quality of the ponds' landscape and direct surroundings, while the ecosystem-based approach (sensu Soto et al. 2008) and profit-oriented, intensive fish farming are not necessarily compatible.

In farmed carp, the growth rate differs depending on climatic conditions and the level of culture intensification. In Europe, carp is usually raised to marketable size in a three-year growing cycle. Carp age classes are stocked in separate growing ponds to adjust farming practices to the age-specific requirements of fish production and to preclude negative intercohort interactions (Kestemont 1995; Pillay and Kutty 2005). Owing to fast weight gain by fish in culture conditions, carp age classes differ substantially in average body size. Given that the ecological impacts of carp are to a large extent related to individual fish size (Driver et al. 2005), and that stocks of young, small-sized fish typically have lower standing biomass than stocks of older and larger fish, farm ponds stocked with agestructured fish constitute heterogeneous systems potentially differing in environmental quality. Although carp diets, both in natural and aquaculture conditions, and the influence of carp on water quality have been widely studied (e.g. Matlak and Matlak 1976; Crivelli 1981; Vilizzi 1998; Rahman et al. 2009), the consequences of carp impacts on the biotic and abiotic characteristics of aquacultural systems have received attention only with regard to the intensification of fish production (Pechar 2000; Potužák et al. 2007) and pond suitability for viable polycultures with other fish species (reviewed in Kestemont 1995; Rahman et al. 2009). Elucidation of the potential differences in age-structured carp effects on pond ecosystem properties, such as water turbidity, is crucial for understanding how to manage available pond resources so as to support functions other than fish production, e.g. 
sustaining of secondary habitats for protected wildlife species, or the delivery of recreational opportunities.

This study aimed to investigate changes in invertebrate communities and water quality along the gradient of three year-classes of cultured carp, i.e. fish in the first, second and third years of growth. During 'snapshot' surveys of fish farms in SE Poland, I examined carp diets, densities of microcrustacean zooplankton and water-column macroinvertebrates and clear water/turbid state variables in ponds stocked with different fish year-classes. As zooplankton and macroinvertebrates constitute the basic trophic links of aquatic systems, their dynamics in the ponds reflect the impact of carp farming practices on pond communities. I focused on the spring-midsummer (April-July) period as the most important, both for the growth of farmed fish and for the environmentally friendly non-aquaculture use of ponds.

\section{Methods}

Study system

The carp ponds examined belonged to six pond-complexes (Garbów, Czesławice, Samoklęski, Piaski, Lipniak and Siemień; in total 651-682 ha of water surface area) around the city of Lublin, SE Poland $\left(51^{\circ} 08^{\prime}-38^{\prime} \mathrm{N}, 22^{\circ} 16^{\prime}-51^{\prime} \mathrm{E}\right)$. The ponds were shallow (range of mean depths: $0.7-1.3 \mathrm{~m}$ with water level fluctuations of up to $0.3 \mathrm{~m}$ ); however, they differed in size (range 1-69 ha) and coverage (range 5-68\%) of emergent aquatic vegetation. Three carp age classes were stocked separately: young-of-the-year $(0+)$ fish, carp after first wintering $(1+)$ and 2-year-old fish $(2+)$. The first year of the production cycle in on-growing ponds was simplified compared to the conventional production cycle (extensive farming practice sensu Horváth et al. 1992), in that rearing of fish from fry (stocked in May at an individual weight of $1.5-3.0 \mathrm{mg}$ ) to fingerlings (ca 40-50 g in autumn) was carried out in a single-stage system, i.e. in fingerling rearing ponds (hereafter: $\mathrm{C} 1$ ponds). Occasionally, when fry stocking was not successful, C1 ponds were re-stocked in June-July with one- or two-month-old fish obtained from farms specialising in rearing advanced fry. Except for a few ponds where fish were left over the winter, the ponds were regularly drained in September-October and the fish were transported to winter ponds. Older age classes were reestablished in growing ponds in April. The approximate ranges of individual fish weight at stocking were $1+$ carp, 30-50 g and $2+$ carp, 150-250 g. The typical stocking densities in ponds with carp after first wintering (hereafter: $\mathrm{C} 2$ ponds) and ponds assigned for market-size production (C3 ponds) were $170-240 \mathrm{~kg} \mathrm{ha}^{-1}$. The collective biomass of additional and wild-grown fish (pike Esox lucius, sunbleak Leucaspius delineatus, tench Tinca tinca, Crucian carp Carassius carassius, golden orfe Leuciscus idus, wels Silurus glanis) did not exceed $3-4 \%$ of the final fish production per pond. Cereal grains were supplied to $0+$ fish from July and to older age classes from May (in the amount of ca 2-3\% of the estimated fish biomass daily). In June and July, liming was carried out with calcium carbonate (ca $20 \mathrm{~kg} \mathrm{ha}^{-1}$ monthly). Prior to fish stocking, fingerling ponds were fertilised with dung from livestock (more details on the study sites are provided in Kloskowski 2009).

Carp diets

Carp individuals from each age class were collected for gut content analyses in spring (throughout May) and in summer (throughout July) in 2001, 2002, 2006 and 2007. Carp 
alimentary tracts were dissected immediately, and their contents were individually frozen for later analysis or immersed in $4 \%$ formalin. In most individuals, the entire contents of the anterior part of the digestive tract were examined in a Sedgewick-Rafter counting chamber, but in the case of the largest specimens they were distilled to $20 \mathrm{ml}$ and mixed, and a subsample (1/5 of the suspension) was examined. Gut contents containing fewer than 20 food particles were rejected from the analysis.

The analyses focused on natural food; in fact, cultured carp bases the substantial part of its growth on natural foods (Schroeder 1983; IUCN 1997). Macrophyte food and detritus masticated and crushed by carp pharyngeal teeth were largely inseparable and difficult to assess quantitatively. However, detritus was apparently of minor importance $(<1 \%$ of the estimated volume) and was absent in alimentary tracts where no cereals were found. Therefore, only their collective proportional volume in the diet (Hyslop 1980) was measured, and only in ca 50\% of the samples from each carp age class. Algae regularly appeared in the gut of all age classes. However, they were omitted from the general diet analyses as their estimated biomass proportion in the gut (dry weights were predicted using published values; compiled in Reynolds 2006) was very low relative to the other food (see 'Results' section). Also, their nutritional contribution remains uncertain, since reports on carp's capability to efficiently digest phytoplankton are contradictory (reviewed in Saha and Ray 1998).

Key body parts were used to sort the animal prey to the genus or family level and to estimate the minimum number of prey individuals. Dry weights of rotifers and microcrustaceans were predicted from published regressions (Dumont et al. 1975; Bottrell et al. 1976). For macroinvertebrate taxa, individual measurements were converted into biomass using length-weight regressions obtained after drying samples collected in the study area to stable weight at $60^{\circ} \mathrm{C}$. The contribution of food categories in the diets was expressed as percentage of total weight of individuals of a prey category relative to the total weight of all food components. Estimated weight of food components was a poor expression of dietary importance as the body length and species identity of prey could rarely be precisely determined, and so average individual biomasses or composite length-weight regressions were largely used. However, this appears superior to methods based on percentage of occurrence or numerical abundance of food items due to disproportions in the individual biomass of prey (Hyslop 1980), e.g. the latter methods can underestimate the role of macroinvertebrate taxa relative to the microcrustaceans.

The degree of intraspecific overlap in diet was evaluated using the Schoener percent similarity index (Schoener 1970). Schoener's index (SI) ranges from 0 (no food is shared) to 1 (complete dietary overlap). Overlap values greater than 0.6 are considered significant (Wallace 1981).

\section{Zooplankton and macroinvertebrates}

Zooplankton sampling was conducted between 23 June and 9 July 2001, and from 27 April to 8 May and from 23 June to 9 July 2002. The spring sampling of C1 ponds was carried out shortly before fish stocking. Zooplankton samples were taken over unvegetated sediments from central parts of each pond with a $27-\mathrm{cm}$-diameter plankton net and concentrated in a 55- $\mu \mathrm{m}$ mesh funnel. The net was drawn vertically from sediment surface to water surface at two locations at least $10 \mathrm{~m}$ apart. Water depth was recorded so that samples could be standardised by volume. Samples were collected in similar weather conditions between 10:00 and 15:00 and preserved immediately in 70\% alcohol. As small rotifers may not have been quantitatively retained with the $55-\mu \mathrm{m}$ mesh net, the analyses 
covered only crustacean zooplankton. Cladocerans were identified to the lowest feasible taxonomic level, copepods to the genera. The plankters were enumerated in SedgewickRafter chambers and measured under an inverted microscope. Samples with abundant numbers of invertebrates were subsampled (subsamples were of at least 200 organisms). Dry weights were predicted from regressions of Dumont et al. (1975) and Bottrell et al. (1976) relating individual plankter length to dry mass.

For analyses, zooplankton were grouped into size-specific functional groups: small cladocerans (mainly Ceriodaphnia sp., Bosmina sp., Chydorus sphaericus), medium- and large-sized cladocerans (mainly Daphnia cucullata, Daphnia magna, Daphnia longispina, Diaphanosoma brachyurum, Simocephalus sp.), nauplii and copepodids, cyclopoid copepods. Other functional groups, consisting of numerically rare taxa with a high sampling variance, i.e. large predacious cladocerans (Polyphemus pediculus and Leptodora kindtii) and calanoids, were omitted.

Water-column macroinvertebrates were sampled between 1 and 20 July 2000 in 65 ponds belonging to four of the pond-complexes studied. Water-column macroinvertebrates were defined here as taxa of body length or width $\geq 0.4 \mathrm{~mm}$ (other than microcrustacean zooplankton) inhabiting the water column. These included phytophilic invertebrates associated with macrophytes suspended in the water column. A strong-handled rigid-frame dip net with a $30-\mathrm{cm}$-diameter opening and 1-mm mesh was used. Ten sweeps were done every $20 \mathrm{~m}$ (estimated by pacing) along the longitudinal axis of the pond. The dip net, operated by the same person, was moved $1 \mathrm{~m}$ horizontally along the pond bottom and then a quick, 1-m vertical sweep was performed up to the surface. The contents of the sweeps were pooled in one composite sample per pond, encompassing $\approx 1.4 \mathrm{~m}^{3}$. The macroinvertebrates collected were identified at least to family level. For analyses, macroinvertebrates were pooled to the most commonly occurring taxonomic groups: Ephemeroptera, Diptera, Odonata (mainly Zygoptera), Heteroptera (mainly Corixidae and Notonectidae) and Coleoptera (mainly Dytiscidae). Other taxa occurred in fewer than 10 ponds.

Turbidity-macrophyte feedback indices

Proportional bottom coverage by submerged macrophytes was estimated as an index of submerged vegetation abundance. Between 15 and 31 July in 2000 and 2001, the presence or absence of vegetation was recorded within a circular frame (40 cm diameter) at 50 locations every $10 \mathrm{~m}$ along 2-3 transects that intersected the pond. Secchi depth was measured using a 23-cm disc during each zooplankton sampling event in 2001 and 2002, and from 27 April to 8 May 2001 (a single measurement per pond) in ponds sampled for zooplankton in summer 2001. Secchi transparency was used as a proxy for water turbidity, as Secchi depth and nephelometric turbidity (measured using a Hach 2110 AN IS turbidimeter) sampled on the same occasions were highly correlated (Pearson $r=-0.578$, $P<0.001, N=36$ ponds).

\section{Statistics}

Multivariate analyses of variance (MANOVA) were conducted as a priori tests (Scheiner 1993) to compare diet composition between carp age classes and between seasons (spring vs. summer) and to compare the densities of the main macroinvertebrate taxa between ponds with different-aged fish stocks. Since preliminary univariate analyses showed that the study site and (in the dietary analyses) the year factor did not significantly affect the models, data from different pond-complexes and years were combined. Following any 
significant MANOVA, univariate analyses of variance (ANOVA) were then performed on individual response variables (taxonomic groups). Finally, Tukey's pair-wise comparisons were made at a significance level of $P<0.05$. The MANOVA used to evaluate differences in macroinvertebrate densities between pond categories included pond surface area (ha) and macrophyte vegetation cover (determined by digitisation from aerial photographs of the ponds and expressed in terms of proportion of pond area covered by emergent vegetation) as covariates. Since this model did not meet the assumptions of the equality of covariance matrices, model significance was evaluated using Pillai's trace, which is more robust than Wilks $\lambda$ to deviations from the assumptions of MANOVA (Scheiner 1993).

Zooplankton data and clear water-turbid phase characteristics were analysed using restricted (residual) maximum likelihood models (REML). REML use was deemed appropriate owing to the presence of some uneven sample sizes across both random and fixed terms. The years and sites (pond-complexes) over which the research was performed, including pond identity (nested as pond/pond-complex), were included as random factors. In ca $40 \%$ of the surveyed ponds, the age of carp stocks changed between years. The age of carp in the pond, pond surface area and emergent vegetation cover were included in the analyses as fixed terms. The non-significant explanatory terms were then discarded in order of lowest effect size, until the model contained only significant terms. Significance of the explanatory terms was assessed using the Wald statistic, which is distributed as $\chi^{2}$. $P$ values were Bonferroni-corrected. The variance matrix derived from REML analysis was used to determine approximate least significant differences (LSDs) among means. For water transparency, which was sampled twice, in spring and summer, a repeated measures model was used. Pond identity and season were included as subject and time factor, respectively. In pond systems with age-distributed carp stocks, the effects of fish individual size are difficult to separate from the effects of fish density, because in spring the total biomass of fry, even when stocked at high numbers, is markedly lower than that of older age classes. Moreover, $1+$ and $2+$ carp were stocked at similar densities. Therefore, since the age (average individual fish size) of carp and the total stock biomass were correlated, to avoid multicollinearity effects they were both represented in the analyses by carp age as a single predictor variable.

For analyses, compositional data, i.e. dietary proportions in carp food and proportions of different functional zooplankton groups, were converted to natural log ratios, in order to transform them into variables that were linearly independent from each other (Aitchison 1986). The 0 values were replaced with 0.001 . The data were analysed using GenStat v. 11.1 (VSN International Ltd) and Statistica v.8. (StatSoft Inc.) software.

\section{Results}

Carp diets

Gut content analyses revealed that with the exception of seeds, plant material was absent from carp diet. Volumetrically, the contribution of supplemented feed cereals and detritus varied considerably in all year-classes (range 0-90\%) and increased on average from $0 \%$ in $0+$ fish collected in May (in spring, carp fry were not fed and no macrophyte remains were retrieved from their alimentary tracts) to $54 \pm$ SE $9 \%$ of the ingesta of $2+$ fishes sampled in July. Algae made up a very small proportion of the diet $(<0.5 \%$ of estimated total biomass in all samples). Chlorophyta and Bacillariophyta dominated algae remains (together $>60 \%$ in all seasonal samples) in the guts of all age classes. 
Composition of carp animal food categorised into three main dietary groups, microcrustacean zooplankton (including ostracods), dipteran and non-dipteran insects (see Table 1), showed strong inter-seasonal (MANOVA: Wilks $\lambda_{3,316}=0.744, P<0.001$ ) and age-dependent (Wilks $\lambda_{6,272}=0.865, P<0.003$ ) variability. From spring to summer, there was a decrease in the consumption of zooplankton (ANOVA $F_{1,138}=45.92$, $P<0.001)$ associated with an increase in the consumption of benthic Diptera $\left(F_{1,138}=15.15, P<0.001\right)$ and of other insects $\left(F_{1,138}=15.02, P<0.008\right)$ in all age classes. Of the main dietary groups, only the zooplankton's contribution to the total dietary intake of animal food varied significantly between age classes $\left(F_{2,138}=4.65, P=0.011\right)$. Tukey post hoc tests revealed significant differences between mean zooplankton proportions in the diet of $0+$ and older age classes (both $P<0.05$ ). Significant amounts of copepods and rotifers were found only in the guts of $0+$ carp. There was also a sizedependent shift in the exploitation of cladocerans. Large-sized grazers, mainly daphnids, were virtually absent in the guts of carp fry in spring, and constituted only $14.4 \%$ of the identified cladocerans in summer, but constituted 80.0 and $67.9 \%$ in $1+$ and $49.0 \%$ and $56.4 \%$ in $2+$ carp, respectively. The remaining cladoceran prey were small-bodied taxa, in all carp age classes dominated by Bosmina sp. Aquatic insects constituted the bulk of the diet (79.3-99.8\%) of carp of all sizes, except spring $0+$ samples, where microcrustaceans made up $45.1 \%$ of carp food. Benthic dipterans were consistently the most important prey item (Table 1). Chironomid larvae and pupae dominated among the dipterans in all seasonal samples (80.7-100.0\%).

Diet overlap was relatively high irrespective of the age of carp both in spring $(\mathrm{SI}=0.62-0.80)$ and in summer $(\mathrm{SI}=0.77-0.89)$. The inter-seasonal overlap of spring and summer food resources was low in $0+$ carp $(\mathrm{SI}=0.47)$, but not in older age classes $(1+, \mathrm{SI}=0.61 ; 2+, \mathrm{SI}=0.73)$.

Table 1 Mean percent biomass of animal food items recorded in guts of $0+, 1+$ and $2+$ carp

\begin{tabular}{|c|c|c|c|c|c|c|}
\hline & \multicolumn{6}{|c|}{ Mean percent biomass } \\
\hline & \multicolumn{3}{|l|}{ Spring } & \multicolumn{3}{|l|}{ Summer } \\
\hline & $0+$ carp & $1+$ carp & $2+$ carp & $0+$ carp & $1+$ carp & $2+$ carp \\
\hline Size range $(\mathrm{TL})$ & $2-5 \mathrm{~cm}$ & $12-14 \mathrm{~cm}$ & $21-24 \mathrm{~cm}$ & $6-10 \mathrm{~cm}$ & $16-20 \mathrm{~cm}$ & $28-31 \mathrm{~cm}$ \\
\hline$N$ & 34 & 21 & 14 & 29 & 23 & 13 \\
\hline \multicolumn{7}{|l|}{ Food category } \\
\hline Rotifera & 2.4 & 0.0 & 0.0 & 0.03 & 0.0 & 0.0 \\
\hline Cladocera & 25.7 & 14.9 & 20.0 & 0.5 & 0.03 & 0.1 \\
\hline Copepoda & 14.4 & 1.1 & 0.2 & 0.3 & 0.04 & 0.1 \\
\hline Ostracoda & 2.6 & 1.0 & 0.3 & 0.0 & 0.0 & 1.2 \\
\hline Trichoptera & 1.4 & 4.5 & 6.8 & 5.0 & 26.3 & 15.7 \\
\hline Ephemeroptera & 2.3 & 0.3 & 2.0 & 7.3 & 2.7 & 5.7 \\
\hline Chironomidae & 31.7 & 53.3 & 63.7 & 75.7 & 68.1 & 74.9 \\
\hline Other Diptera & 7.6 & 10.0 & 0.5 & 8.2 & 0.0 & 0.0 \\
\hline Zygoptera & 2.0 & 2.2 & 0.2 & 1.4 & 2.7 & 2.2 \\
\hline Other insects & 5.5 & 9.3 & 6.1 & 1.2 & 0.0 & 0.0 \\
\hline $\begin{array}{l}\text { Other prey (Nematoda, Oligochaeta, } \\
\text { Hydracarina) }\end{array}$ & 4.3 & 3.4 & 0.1 & 0.2 & 0.04 & 0.0 \\
\hline
\end{tabular}




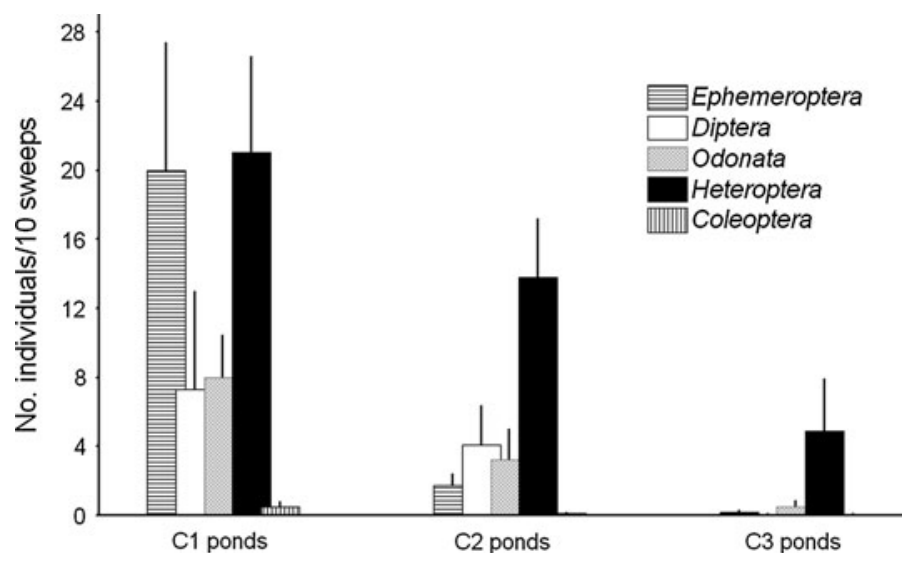

Fig. 1 Mean abundance of macroinvertebrate taxa in ponds with different-aged carp stocks. Error bars represent $+1 \mathrm{SE}$. Fingerling ponds $(\mathrm{C} 1), N=21$; on-growing ponds (C2), $N=29$; ponds with market-size fish (C3), $N=15$

\section{Zooplankton and macroinvertebrates}

Total zooplankton biomass did not differ between ponds stocked with different age classes, either in spring 2002 (REML Wald $\chi_{2}^{2}=0.83, P=0.668$ ) or in summer (combined 2001 and 2002 with year as a random factor; $\left.\chi_{2}^{2}=0.75, P=0.689\right)$. In spring, the mean biomasses of the functional groups of zooplankton analysed did not differ significantly between the different pond categories (Table 2). In summer, the mean biomass of mediumand large-bodied cladocerans significantly declined along the carp age gradient, while the biomass of cyclopoid copepods, but not their nauplii and copepodits, increased. However, the differences in the abundance of medium- and large-bodied cladocerans were significant only between $\mathrm{C} 1$ ponds and ponds stocked with older age classes (Table 2). When zooplankton composition was analysed in terms of proportions, only the biomass proportion of medium-sized and large cladocerans varied significantly with carp age, being higher in $\mathrm{C} 1$ ponds than in $\mathrm{C} 2$ and $\mathrm{C} 3$ ponds (Wald $\chi_{2}^{2}=7.03, P=0.034$ ). The explanatory terms other than carp age were insignificant in all REML models.

Densities of macroinvertebrates were significantly affected by the age of carp in the ponds (MANOVA, Pillai's trace $=0.349, F_{10,112}=2.51, P=0.007$; covariates: Pillai's trace $\left.=0.159, F_{10,112}=0.98, P=0.71\right)$. With the exception of Diptera (ANOVA, $F_{2,60}=$ $1.31, P=0.276)$ there were differences in the densities of all individual macroinvertebrate groups between pond categories (all $F_{2,60} \geq 3.21, P \leq 0.047$ ). In all macroinvertebrate taxa, densities decreased with carp age (Fig. 1), but the differences between pond categories (Tukey's pair-wise comparisons; at $P<0.05$ ) were significant only in Ephemeroptera and Odonata between $0+$ and older carp cohorts.

Turbidity-macrophyte feedback characteristics

Submerged macrophyte cover and water transparency decreased with increasing carp age in the ponds, but significant differences were found only between ponds stocked with $0+$ and older cohorts (Table 3). Water transparency estimates may be considered conservative given that the Secchi disc was frequently visible throughout the water column in $0+$ ponds. 
Table 2 Mean abundance of the principal functional groups of zooplankton in C1, C2 and C3 carp ponds

\begin{tabular}{|c|c|c|c|c|c|c|}
\hline Season & Taxon & $\begin{array}{l}\text { C1 } \\
\text { ponds }\end{array}$ & $\begin{array}{l}\mathrm{C} 2 \\
\text { ponds }\end{array}$ & $\begin{array}{l}\text { C3 } \\
\text { ponds }\end{array}$ & SED & $\begin{array}{l}\text { Wald } \chi^{2} \\
(d f=2)\end{array}$ \\
\hline \multirow[t]{4}{*}{$\begin{array}{l}\text { Spring (late April-early May } \\
\text { 2002, } N=52 \text { ) }\end{array}$} & $\begin{array}{l}\text { Small-sized } \\
\text { cladocerans }\end{array}$ & $69.72^{\mathrm{a}}$ & $61.56^{\mathrm{a}}$ & $59.27^{\mathrm{a}}$ & 2.93 & 0.06 \\
\hline & $\begin{array}{l}\text { Medium- and large- } \\
\text { sized cladocerans }\end{array}$ & $123.21^{\mathrm{a}}$ & $137.12^{\mathrm{a}}$ & $90.63^{\mathrm{a}}$ & 4.18 & 0.27 \\
\hline & $\begin{array}{l}\text { Nauplii and } \\
\text { copepodids }\end{array}$ & $66.41^{\mathrm{a}}$ & $48.43^{\mathrm{a}}$ & $44.40^{\mathrm{a}}$ & 1.95 & 0.69 \\
\hline & Cyclopoid copepods & $79.75^{\mathrm{a}}$ & $157.25^{\mathrm{a}}$ & $106.30^{\mathrm{a}}$ & 2.48 & 2.57 \\
\hline \multirow[t]{4}{*}{$\begin{array}{l}\text { Summer (late June-early July; } \\
\text { 2001, } N=53 ; 2002, N=58 \text { ) }\end{array}$} & $\begin{array}{l}\text { Small-sized } \\
\text { cladocerans }\end{array}$ & $35.04^{\mathrm{a}}$ & $47.21^{\mathrm{a}}$ & $63.33^{\mathrm{a}}$ & 2.10 & 0.94 \\
\hline & $\begin{array}{l}\text { Medium- and large- } \\
\text { sized cladocerans }\end{array}$ & $137.19^{\mathrm{a}}$ & $35.02^{\mathrm{b}}$ & $32.35^{\mathrm{b}}$ & 2.76 & $7.87 *$ \\
\hline & $\begin{array}{l}\text { Nauplii and } \\
\text { copepodids }\end{array}$ & $57.17^{\mathrm{a}}$ & $42.72^{\mathrm{a}}$ & $57.68^{\mathrm{a}}$ & 1.29 & 0.97 \\
\hline & Cyclopoid copepods & $44.68^{\mathrm{a}}$ & $84.73^{\mathrm{a}, \mathrm{b}}$ & $132.00^{\mathrm{b}}$ & 1.79 & $7.43 *$ \\
\hline
\end{tabular}

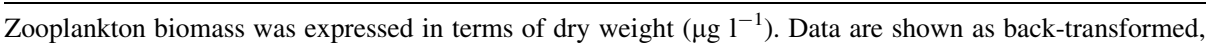
REML-adjusted means (analyses were performed on sqrt-transformed data). Values with the same superscript are not significantly different by LSD test at $P<0.05$. SED average standard error of the differences for carp year-classes. SEDs were not back-transformed. $* P<0.05$

Table 3 Submerged macrophyte cover and water transparency (REML predicted means) in C1, C2 and C3 carp ponds

\begin{tabular}{llllll}
\hline & C1 ponds & C2 ponds & C3 ponds & SED & Wald $(d f=2)$ \\
\hline Proportional vegetation cover & \multicolumn{1}{c}{$0.534^{\mathrm{a}}$} & $0.218^{\mathrm{b}}$ & $0.160^{\mathrm{b}}$ & 0.107 & $13.67^{*}$ \\
Secchi depth $(\mathrm{cm})$-spring & $112.4^{\mathrm{a}}$ & $91.3^{\mathrm{b}}$ & $80.1^{\mathrm{b}}$ & 0.095 & $13.39^{*}$ \\
Secchi depth $(\mathrm{cm})$-summer & $114.4^{\mathrm{a}}$ & $60.8^{\mathrm{b}}$ & $54.9^{\mathrm{b}}$ & 0.049 & $70.77^{*}$ \\
\hline
\end{tabular}

The age of carp was the only statistically significant factor in all models. Macrophyte cover, sample sizes: 2000, $N=51 ; 2001, N=49$. Secchi depth analyses (sample sizes the same as in Table 2) were performed on log-transformed data. For clarity, back-transformed predicted means are shown. SEDs were not backtransformed. Values with the same superscript are not significantly different by LSD test at $P<0.05$

$* P<0.01$

Repeated REML measures did not show overall seasonal changes in Secchi depth (Wald $\chi_{3}^{2}$ $=28.37, P<0.001)$, but when carp age classes were analysed separately, Secchi depth did not change only in $0+$ ponds (Wald $\chi_{1}^{2}=0.05, P=0.830$ ) and decreased over the season in ponds stocked with older cohorts (both Wald $\chi_{1}^{2} \geq 4.42, P \leq 0.04$ ).

\section{Discussion}

Carp can strongly suppress invertebrate abundance and taxa richness, although the relative magnitudes of the direct trophic influence and the indirect effects of carp, such as elevated turbidity and macrophyte loss, have yet to be differentiated (e.g. Miller and Crowl 2006; Matsuzaki et al. 2007; Kloskowski 2011). The diet of cultured carp did not show significant changes between young-of-the-year and older fish, except for the stronger use of 
zooplankton by $0+$ carp than by later developmental stages (cf. Rahman et al. 2009). Benthic macroinvertebrates constituted an important component of the diet as early as at an individual fish size of $3-5 \mathrm{~cm}$. This indicates that in carp the shift to probing the bottom may occur at a very early ontogenetic stage (see also Adzhimuradov 1972; Matlak and Matlak 1976; Vilizzi 1998). Carp prefer benthic macroinvertebrates over zooplankton (Rahman et al. 2010), but it is not clear whether the importance of zooplankton in the spring diet of $\geq 1+$ carp was related to the relatively lower availability of benthic resources in spring. Despite the early shift to benthivory, $1+$ and $2+$ carp also take food from the water column, and the mean total biomass of water-column macroinvertebrates was lower in $\mathrm{C} 2$ and $\mathrm{C} 3$ ponds than in ponds with younger fish. Although zooplankton was more important in the diet of $0+$ carp, older/larger fish were better capable of exploiting largesized cladoceran grazers, presumably because their size-selective food filtering system favours the retention of large-sized zooplankton (Sibbing 1988). No significant differences in total zooplankton biomass were detected, but zooplankton community structure differed between pond categories. In summer, abundance of medium- and large-sized cladocerans was considerably lower in $\mathrm{C} 2$ and $\mathrm{C} 3$ ponds than in $\mathrm{C} 1$ ponds, a possible consequence of depredation by $\geq 1+$ carp in spring. Summer zooplankton community composition in ponds with older-age carp was typical for fish planktivory, when mainly large-sized cladocerans are reduced, while copepods, which are better able to avoid fish predation, and small-sized species like Bosmina dominate (Lazzaro 1987; Potužák et al. 2007). Daphnids have been suggested to be more important for phytoplankton control than collective zooplankton abundance (Brooks and Dodson 1965; Timms and Moss 1984). Surveys of chlorophyll a concentrations conducted in the ponds in July 2006 and 2007 revealed significantly higher phytoplankton abundance in ponds stocked with older age classes than those with 0+ carp (Kloskowski 2011). These results support the hypothesis of a trophic cascade in the presence of large-sized carp (Havens 1993; Khan et al. 2003).

The depredation of phytoplankton grazers by fish is only one of the possible mechanisms leading to differences in water quality between pond categories. Carp may damage the macrophytes by disrupting bottom sediment (Sidorkewicj et al. 1999; Miller and Crowl 2006) and indirectly contribute to the elimination of large-bodied grazers as well, since high turbidity interferes with their foraging on algae (Kirk 1991). Resuspension of sediment and algae reduces penetration of light under the water and its availability for submergent vegetation (Hellström 1991; Sidorkewicj et al. 1999). These effects may be stronger in the presence of larger carp, which are capable of penetrating deeper in a substratum than smaller fish (Panek 1987), and more intense in summer when carp take mainly benthic prey. Carp bioturbation is vital to the persistence of aquatic communities, since elevated sediment concentrations can smother invertebrate eggs, suffocate fish embryos and potentially reduce the respiratory capabilities of amphibian larvae by fouling their gills (deMaynadier and Hunter 1995; Belsky et al. 1999; Gleason et al. 2003). Moreover, benthivorous fish expel large quantities of nutrients into the water column, thus enhancing phytoplankton production (Andersson et al. 1988; Qin and Threlkeld 1990; Matsuzaki et al. 2007). The latter mechanism might have been especially important in ponds with older carp, which received supplemental food from the onset of the growing season. Although adding of nutrients may be a less important mechanism affecting zooplankton and algal populations than zooplankton grazing by carp, the strong influence of artificial fertilisation on zooplankton and algae in ponds may confound the cascade effects (Khan et al. 2003; Havens 1993). Ponds with older-age carp were characterised by relatively high water clarity in spring, but not in summer, and at the end of July and in August blue-green algae blooms were observed (Kloskowski et al. 2010; cf. Szumiec et al. 1995). 
In early spring, the development of phytoplankton is restricted by relatively low nutrient excretion rates by fish, whereas depletion of phytoplankton-controlling cladocerans could be delayed due to reduced feeding activity of carp in low water temperature conditions (Crivelli 1981; Garcia and Adelman 1985). In summer, at high nutrient loading in high water temperature (favouring anoxic conditions), the proliferation of phytoplankton can induce nitrogen deficit and trigger cyanobacteria blooms (Szumiec et al. 1995; Billard 1999).

Carp effects on environmental conditions are size dependent and density dependent (for a review see Weber and Brown 2009). Since in monoculture ponds with age-structured stocks the stocking biomass of older age classes is naturally greater than that of fry, the effects ascribed to carp age combine the effects of both individual fish size and total biomass without differentiating their relative strength. At high fish densities, carp impact on pond communities can be expected to be enhanced (Billard 1999). This poses the problem of maintaining fish density levels compatible with ecosystem services to humans and wildlife, i.e. total stocking biomass should be lower than the critical threshold for a rapid switch to a macrophyte-poor turbid state (approximately $250-450 \mathrm{~kg} \mathrm{ha}^{-1}$ in systems where detrimental carp impact was documented; reviewed in Weber and Brown 2009). Concerns about fish densities apply mainly to ponds with older carp age classes; due to minute individual biomass of fry the critical levels of collective biomass can be attained in temperate conditions by $0+$ stocks only late in the growing season.

Aquatic recreational services rely heavily on the environmental quality of the waters, and at farm ponds they should be diversified according to the differential impacts of agedistributed fish stocks. Turbid waters exhibit poor biodiversity (Miller and Crowl 2006; Matsuzaki et al. 2007) and their recreational use by humans is not free from potential health and safety hazards (WHO 2003). In contrast, clear-water ponds with relatively abundant submerged vegetation and lacking fish predators attract breeding amphibians, while rich invertebrate resources benefit breeding waterfowl (Mallory et al. 1994; Nummi and Pöysä 1995; Kloskowski et al. 2010). Most studies on fish-waterfowl interactions stress that fishless habitats are more abundant in macroinvertebrates than those with fish and thus more suitable for birds (e.g. Huener and Kadlec 1992; Mallory et al. 1994). Carp in their first spring and summer are too small to significantly affect aquatic macroinvertebrates; consequently, $\mathrm{C} 1$ ponds can host a wide range of waterfowl species dependent on invertebrate food for breeding. Overall, $\mathrm{C} 1$ ponds appear to best meet the demands of environmentally friendly multifunctional use: besides fish production they provide habitats that are recognised as potential hotspots of animal diversity (Kloskowski 2010). Potential losses in fish yield because of non-aquaculture use are economically the least costly at $\mathrm{C} 1$ ponds. Therefore, these ponds provide the smallest area for conflict between the demands of ecological sustainability and the economic imperatives of stakeholders (see also Arlinghaus 2006). Still, proper management of C2 and C3 ponds can increase their capacity for non-aquaculture use, e.g. the maintenance of abundant emergent vegetation stands along the pond margins can enhance landscape appearance and improve its suitability as a habitat for endangered wildlife species (Hartel et al. 2007; Kloskowski et al. 2010). Nonbreeding wildfowl may select habitat to minimise disturbance or predation risk, or alternate between habitats for feeding and roosting (Tamisier 1978); therefore, the largest ponds at the fish farms, typically containing marketable fish (Billard 1999), can provide birds with protection from disturbance.

The prevention of cyanobacterial blooms and the stabilisation of dissolved oxygen concentrations by adequate farming practices (cf. Potužák et al. 2007), at least until late summer, may be substantially important for visual effects of the pond landscape and for 
recreational use of ponds with $1+$ or $2+$ carp in spring. It is also crucial for sustaining pond biodiversity; in temperate zones, up to the end of July many aquatic insect taxa and most amphibians complete metamorphosis to adult forms, and the breeding season of most waterbirds is over. A practical alternative to improve the environmental quality of ponds with older carp might be an appropriate choice of fish species (and their densities) to be stocked in polycultures with carp. Specific foraging specialisations and synergistic interactions among fish species may help to buffer ammonia levels, balance oxygen conditions and control excessive algal blooms in carp ponds (reviewed by Milstein 1992; but see Opuszyński 1981; Pechar 2000). In consideration of water quality improvement, the species best suitable for polyculture with common carp are the phytophagous silver carp and grass carp (Opuszyński 1981; Piotrowska-Opuszyńska 1984). However, so far little is known about the implications of polyculture for biodiversity of farm ponds. Given that combined cultures of ecologically different species require much more complex management than monocultures and (especially when the approach is ecosystem-oriented) the reduction in stocking densities may be necessary (Milstein 1992; Pillay and Kutty 2005), polyculture in carp ponds involves financial risks and the benefits of stocking additional fish species are highly dependent on local environmental conditions (reviewed in Kestemont 1995).

Acknowledgments I would like to thank M. Nieoczym, E. Kaczanowska, G. Kahlan and M. Adamczuk for field and laboratory assistance. I appreciate the access to the ponds given by the pond owners, $\mathrm{M}$. Filipiak, E. Lagowski, J. Orzepowski, G. Olszak and M. Sagan. The comments of two anonymous reviewers significantly improved the manuscript. This study was supported by the State Committee for Scientific Research grant KBN 6 P04F 06620.

Open Access This article is distributed under the terms of the Creative Commons Attribution Noncommercial License which permits any noncommercial use, distribution, and reproduction in any medium, provided the original author(s) and source are credited.

\section{References}

Adzhimuradov KA (1972) The food of juvenile carp (Cyprinus carpio (L.)) in early development stanzas in bodies of water of the Arakum (Terek river delta). J Ichthyol 12:981-986

Aitchison J (1986) The statistical analysis of compositional data. Chapman and Hall, London

Andersson G, Graneli W, Stenson J (1988) The influence of animals on phosphorus cycling in lake ecosystems. Hydrobiologia 170:267-284

Aps R, Sharp R, Kutonova T (comp) (2004) Freshwater fisheries in central and Eastern Europe: the Challenge of Sustainability. IUCN, Warsaw

Arlinghaus R (2006) Overcoming human obstacles to conservation of recreational fishery resources, with emphasis on Europe. Environ Conserv 33:46-59

Bekefi E, Varadi L (2007) Multifunctional pond fish farms in Hangary. Aquacult Int 15:227-233

Belsky J, Matzke A, Uselman S (1999) Survey of livestock influence on stream and riparian ecosystems in the western United States. J Soil Water Cons 54:419-431

Billard R (ed) (1999) Carp: biology and culture. Springer, Berlin

Bottrell HH, Duncan A, Gliwicz ZM, Grygierek E, Herzig A, Hillbricht-Ilkowska A, Kurasawa H, Larsson P, Węgleńska T (1976) A review of some problem in zooplankton production studies. Norw J Zool 24:419-456

Brooks JL, Dodson SI (1965) Predation, body size and composition of plankton. Science 150:28-35

Crivelli AJ (1981) The biology of the common carp, Cyprinus carpio L. in the Camargue, southern France. J Fish Biol 18:271-290

deMaynadier PG, Hunter ML (1995) The relationship between forest management and amphibian ecology: a review of the North American literature. Environ Rev 3:230-261 
Driver PD, Closs GP, Koen T (2005) The effects of size and density of carp (Cyprinus carpio L.) on water quality in an experimental pond. Arch Hydrobiol 163:117-131

Dumont HJ, Van De Velde I, Dumont S (1975) The dry weight estimate of biomass in a selection of Cladocera, Copepoda and Rotifera from plankton, periphyton and benthos of continental waters. Oecologia 19:75-97

EPCN (European Pond Conservation Network) (2007) Developing the pond manifesto. Ann Limnol-Int J Lim 43:221-232

Garcia LM, Adelman IR (1985) An in situ estimate of daily food consumption and alimentary canal evacuation rates of common carp, Cyprinus carpio L. J Fish Biol 27:487-493

Gleason RA, Euliss NH Jr, Hubbard DE, Duffy WG (2003) Effects of sediment load on emergence of aquatic invertebrates and plants from wetland soil egg and seed banks. Wetlands 23:26-34

Grimmet RFA, Jones TA (1989) Important bird areas in Europe. ICBP Technical Publication No. 9, Cambridge

Hartel T, Nemes Sz, Cogalniceanu D, Öllerer K, Schweiger O, Moga CI, Demeter L (2007) The effect of fish and aquatic habitat complexity on amphibians. Hydrobiologia 583:173-182

Havens KE (1993) Responses to experimental fish manipulation in a shallow, hypereutrophic lake: the relative importance of benthic nutrient recycling and trophic cascade. Hydrobiologia 254:73-80

Hellström T (1991) The effect of resuspension on algal production in a shallow lake. Hydrobiologia 213:183-190

Horváth L, Tamás G, Seagrave C (1992) Carp and pond fish culture. Fishing News Books, Oxford

Huener JD, Kadlec JA (1992) Macroinvertebrates response to marsh management strategies in Utah. Wetlands 12:72-78

Hyslop EJ (1980) Stomach contents analysis-a review of methods and their application. J Fish Biol 17:411-429

IUCN (International Union for Conservation of Nature) (1997) Fishing for a living-the ecology and economics of fishponds in central Europe. Environmental Research Serie 11. IUCN, Gland

Kestemont P (1995) Different systems of carp production and their impacts on the environment. Aquaculture 129:347-372

Khan TA, Wilson ME, Khan MI (2003) Evidence for invasive carp mediated trophic cascade in shallow lakes of western Victoria, Australia. Hydrobiologia 506:465-472

Kirk KL (1991) Suspended clay reduces Daphnia feeding rate: behavioural mechanisms. Freshw Biol 25:357-365

Kloskowski J (2009) Size-structured effects of common carp on reproduction of pond-breeding amphibians. Hydrobiologia 635:205-213

Kloskowski J (2010) Fish farms as amphibian habitats: factors affecting amphibian species richness and community structure at carp ponds in Poland. Environ Conserv 37:187-194

Kloskowski J (2011) Impact of common carp Cyprinus carpio on aquatic communities: direct trophic effects versus habitat deterioration. Fundam Appl Limnol 178:245-255

Kloskowski J, Nieoczym M, Polak M, Pitucha P (2010) Habitat selection by breeding waterbirds at ponds with size-structured fish populations. Naturwissenschaften 97:673-682

Lazzaro X (1987) A review of planktivorous fishes: their evolution, feeding behaviours, selectivities, and impacts. Hydrobiologia 146:97-167

Mallory ML, Blancher PJ, Weatherhead PJ, McNicol DK (1994) Presence or absence of fish as a cue to macroinvertebrate abundance in boreal wetlands. Hydrobiologia 279-280:345-351

Matlak J, Matlak O (1976) The natural food of carp fry (Cyprinus carpio L.). Acta Hydrobiol 18:203-228

Matsuzaki SS, Usio N, Takamura N, Washitani I (2007) Effects of common carp on nutrient dynamics and littoral community composition: roles of excretion and bioturbation. Fundam Appl Limnol 168:27-38

Miller SA, Crowl TA (2006) Effects of common carp (Cyprinus carpio) on macrophytes and invertebrate communities in a shallow lake. Freshw Biol 51:85-94

Milstein A (1992) Ecological aspects of fish species interactions in polyculture ponds. Hydrobiologia 231:177-186

Nummi P, Pöysä H (1995) Habitat use by different-aged duck broods and juvenile ducks. Wildl Biol 1:181-187

Opuszyński K (1981) Comparison of the usefulness of the silver carp and the bighead carp as additional fish in carp ponds. Aquaculture 25:223-233

Panek FM (1987) Biology and ecology of carp. In: Cooper EL (ed) Carp in North America. American Fisheries Society, Bethesda, MD, pp 1-15

Pechar L (2000) Impacts of long-term changes in fishery management on the trophic level and water quality in Czech fish ponds. Fish Manage Ecol 7:23-32

Pillay TVR, Kutty MN (2005) Aquaculture. Principles and practices, Blackwell, London 
Piotrowska-Opuszyńska W (1984) Impact of the silver carp (Hypophthalmichthys molitrix) (Val.) on the ecosystem of carp ponds. Ekol pol 32:307-339

Potužák J, Hůda J, Pechar L (2007) Changes in fish production effectivity in eutrophic fishponds-impact of zooplankton structure. Aquacult Int 15:201-210

Qin JG, Threlkeld ST (1990) Experimental comparison of the effects of benthivorous fish and planktivorous fish on plankton community structure. Arch Hydrobiol 119:121-141

Rahman MM, Hossain MY, Jo Q, Kim S, Ohtomi J, Meyer C (2009) Ontogenetic shift in dietary preference and low dietary overlap in rohu (Labeo rohita) and common carp (Cyprinus carpio) in semi-intensive polyculture ponds. Ichthyol Res 56:28-36

Rahman MM, Kadowaki S, Balcombe SR, Wahab MA (2010) Common carp (Cyprinus carpio L.) alters its feeding niche in response to changing food resources: direct observations in simulated ponds. Ecol Res 25:303-309

Saha AK, Ray AK (1998) Cellulase activity in rohu fingerlings. Aquacult Int 6:281-291

Scheffer M (1990) Multiplicity of stable states in freshwater systems. Hydrobiologia 200/201:475-486

Scheiner SM (1993) MANOVA: multiple response variables and multispecies interactions. In: Scheiner SM, Gurevitch J (eds) Design and analysis of ecological experiments. Chapman and Hall, New York, pp 94-112

Schoener TW (1970) Non synchronous spatial overlap of lizards in patchy habitats. Ecology 51:408-418

Schroeder GL (1983) Sources of fish and prawn growth in polyculture ponds as indicated by delta C analysis. Aquaculture 35:29-42

Sibbing FA (1988) Specialization and limitations in the utilization of food resources by the carp, Cyprinus carpio: a study on oral food processing. Environ Biol Fish 22:161-178

Sidorkewicj NS, Lopez Cazorla AC, Fernandez OA, Möckel GC, Burgos MA (1999) Effects of Cyprinus carpio on Potamogeton pectinatus in experimental culture: the incidence of the periphyton. Hydrobiologia 415:13-19

Soto D et al (2008) Applying an ecosystem-based approach to aquaculture: principles, scales and some management measures. In: Soto D, Aguilar-Manjarrez J, Hishamunda N (eds) Building an ecosystem approach to aquaculture. FAO/Universitat de les Illes Balears. Expert Workshop, Palma de Mallorca, May 2007. FAO fisheries and aquaculture proceedings. no. 14. FAO, Rome

Szücs I, Stundi L, Váradi L (2007) Carp farming in Central and Eastern Europe and a case study in multifunctional aquaculture. In: Leung PS, Lee C-S, O'Bryan PJ (eds) Species and system selection for sustainable aquaculture. Blackwell Publishing, Ames, pp 389-413

Szumiec MA, Jakubas M, Kolasa-Jamińska B, Urbaniec-Brózda W (1995) Diel, seasonal, and spatial variability in the carp pond ecosystem. Acta Hydrobiol 37:165-172

Tamisier A (1978) The functional units of wintering ducks: a spatial integration of their comfort and feeding requirements. Verh Orn Ges Bayern 23:229-238

Timms RM, Moss B (1984) Prevention of growth of potentially dense phytoplankton populations by zooplankton grazing, in the presence of zooplanktivorous fish, in a shallow wetland ecosystem. Limnol Oceangr 29:472-486

Vilizzi L (1998) Observations on ontogenetic shifts in the diet of 0+ carp, Cyprinus carpio L., from the River Murray, Australia. Folia Zool 47:225-229

Wallace RK (1981) An assessment of diet-overlap indexes. Trans Am Fish Soc 110:72-76

Weber MJ, Brown ML (2009) Effects of Common Carp on Aquatic Ecosystems 80 Years after "Carp as a Dominant": Ecological Insights for Fisheries Management. Rev Fish Sci 17:524-537

WHO (World Health Organization) (2003) Guidelines for safe recreational water environments. WHO, Geneva 